\title{
An Assessment of the Usage of the Lagos Mass Transit Trains
}

\author{
Oni, S. $\mathbf{I}^{\dagger}$ and Okanlawon, K. R.
}

\begin{abstract}
The rail sector, despite its potential for curtailing the present chaotic transport situation in Lagos, remains inefficient and underutilized. In spite of past initiatives and the current attempt by the Lagos State Government to provide a mass transit rail service in Lagos, the share of rail mode in the transport sector has not been encouraging and the railway plays an insignificant role in urban mass transit in Lagos at present. This paper sets out to assess the usage of the Lagos mass transit trains. Hence, the paper determines the passenger traffic flow along the rail route in Lagos and the number of passengers carried between 2000 and 2009 by the Lagos Mass Transit Trains (LMTT) with a view to assessing the usage of the present LMTT. This paper also discusses the historical development of Nigerian railway and describes rail transport in Lagos. Data were obtained through secondary sources coupled with review of literature. The result of this study shows that for a period of 10 years (2000-2009), Lagos mass transit trains carried a total of 9,870,101 passengers, which gives an average of 987,010 passengers annually. This suggests that the service of the Lagos mass transit train is grossly underutilized. However, LMTT contributes enormously to NRC by carrying $68.5 \%$ of the total passenger traffic of NRC between 2000 and 2009. In terms of passenger traffic flow along the route of LMTT, for a period of 1 year, Agbado station recorded the largest number of passengers $(393,811)$, followed by Ijoko $(163,652)$ and Iddo $(120,787)$, while Iganmu station has the lowest number of rail commuters $(16,919)$. This study also discloses that the major commodities hauled by Lagos district of NRC from Lagos to the northern parts of the country in 2007 are Cars, Cement, Billet and Wheat.
\end{abstract}

Key words : Lagos mass transit trains, Transport, Passenger, Development, Railway

\section{Introduction}

Transport is a vital link that binds together the various component of a nation's economy on whatever scale and at whatever level (Adefolalu, 1993). Thus, efficient functioning of the urban life and economy depends to a large extent on the adequacy and efficiency of its transport system. Efforts have been made in the past at solving the problem of traffic congestion in Lagos through the construction of bridges, ring roads, and expressways; restriction of access to the city centre on alternate days between vehicles with odd and even registration numbers; and the conversion of previously two-way roads to one-way. Although these efforts have yielded some results, they have not done much to solve the problem of traffic con-

\footnotetext{
Corresponding author: Department of Geography, University of Lagos, Akoka, Lagos.

E-mail : iyiolaoni@yahoo.com, kemiokanlawon@email.com
}

gestion, particularly during peak periods. A single means of travel cannot serve adequately the intra-urban needs of the majority of people living in the urban environment, especially where an urban environment (Lagos for instance) has a terrain that is dominated by water. There is therefore the need to have a modal split to share the total number of person trips - by rail, road and water transportation system. This will go a long way to reduce traffic congestion in Lagos. In actual fact, mass rail transit is increasingly being suggested as an important means of resolving the transportation situation in Lagos (Mabogunje, 2007).

Rail transport mode exists as the mainframe or pivot around which an integrated national transport system is built with other modes complementing it. Its capacity, which enables it carry large number of passengers and goods safely and securely over long distances at lower unit costs than other modes, also places it in good stead to serve as the $h u b$ of transport system of any nation (Nwanze, 2002). Many developed countries' mega-cities 
such as Moscow, Buenos Aires and Bombay are heavily dependent on rail for urban transport. Lagos is probably the only mega- city in the world without an efficient rail mass transit system.

Rail transport has been continuously developed through innovations, technical and commercial changes while railway speed record is being constantly improved. For instance, portions of the French high-speed rail system can reach speeds up to $515 \mathrm{~km} / \mathrm{hr}$ (Rodrigue and Slack, 2009). International Labour Organization (1994) stated that for intercity travel, medium and high-speed rail travels constitute the first valid alternative to car and air travel in the increasingly congested road and air route networks. Some key factors promoting high-speed rail are that airports and highways may have no room to expand, and are often overloaded, while high-speed rail has the potential for high capacity on its fixed corridors, and has the potential to relieve congestion on the other systems (URL 1). However, the railway system in Lagos/Nigeria when compared with those in advanced countries of the world, still plays an insignificant role in urban mass transit and transportation as a whole.

In the first half of the twentieth century, railways enjoyed unchallenged domination of both freight and passenger traffic movement in Nigeria while road transport, now a competitive threat to the railways, was initially developed to feed them (Olanrewaju, 1986). Nigerian railways have played an immense role in the country's socioeconomic development, helping to open up the hinterland, providing impetus for foreign and domestic trade, agricultural and industrial development as well as stimulating rapid urbanization. However, five decades after independence, the Nigerian railway system remains almost static in structure and is highly unresponsive to the emerging socio-economic and political challenges. Hence the railway system no longer exerts a strong influence nor plays a competitive role in modern Nigeria and particularly in Lagos State in which the nation's commercial capital is located.

In line with global trends for mega population centres like Lagos to have effective modern rail mass transit systems, the Lagos Metropolitan Area Transport Authority (LAMATA) developed a rail master plan, which would create a network of urban rail-based systems covering three major corridors of high commuter traffic demand: The North-South corridor between Ijoko-Alagbado and Iddo along the Nigerian Railway corridor (will be established on the same right- of - way as the proposed national high-speed railway from Iddo to Kano); the East -West corridor along the Ojo-Okokomaiko to Mile 2 axis; the Eastern corridor to serve the emerging development along the Lekki to Epe axis; and a central ring between Victoria Island and Lagos Island connecting the three corridors (LAMATA, 2006; Mabogunje, 2007). A Memorandum of Understanding between LAMATA and NRC was signed in 2006, to grant access to the $100 \mathrm{ft}$ of NRC right-of -way required for the construction of the Light Rail Mass Transit line (URL 2). Rail mass transit is needed now, more so that the existing modes of transportation in Lagos cannot cope effectively with the movement of passengers and freight.

Efforts aimed at rehabilitating the railway system to enhance its performance in Lagos and Nigeria as a whole included a technical cooperation agreement signed between the NRC and the Rail India Technical and Economic Services between 1979 and 1982. Between 1995 1999 and from 2009 till date, fresh technical cooperation agreements were entered between the NRC and the China Civil Engineering Construction Corporation (CCECC). These agreements centered on improving rail tracks and communications facilities; rehabilitation of existing locomotives, coaches and wagons as well as supply of new ones; and re-opening of hitherto closed routes. Thus, on the $30^{\text {th }}$ of October 2006, the Federal Government and the China Civil Engineering Construction Corporation signed an \$8.3billion contract for the construction of a standard gauge railway line covering $1,315 \mathrm{~km}$ from Lagos to Kano. Besides, the Lagos State Government in conjunction with NRC launched the Jubilee Rail Service in November 1992 to expand the rail commuter service in the state. While it lasted, the arrangement was epileptic as it was bedeviled with problems such as time-scheduling, staffing, ticketing, revenue sharing, cost-sharing, lack of infrastructure like car parks and high cost of operations. The Lagos Metropolis Mass Transit Train Service run by the Lagos district of NRC was launched in Lagos on the $26^{\text {th }}$ April, 2001. Presently, the Lagos State Government through the Lagos Metropolitan Area Transport Authority (LAMATA) has taken up the challenge of developing an efficient Light Rail Mass Transit for Lagos.

\section{Historical Development of Nigerian Railways}

The general objective of railway construction in Nigeria between 1898 and 1927 was partly to maintain links between the central seat of colonial government in Lagos and other parts of the country. It was also intended in the words of the Act setting up the Nigerian Railway Corporation to engage as "carriage of passengers and goods in a manner that will offer full value for money, meet cost of operations, improve market share and quality of service, 
Table 1. The Development of Rail Construction in Nigeria

\begin{tabular}{|l|l|l|}
\hline Section & Year & Distance \\
\hline Lagos - Ibadan & $1898-1901$ & $193 \mathrm{~km}$ \\
\hline Ibadan - Jebba & $1901-1909$ & $295 \mathrm{~km}$ \\
\hline Kano - Baro & $1907-1911$ & $562 \mathrm{~km}$ \\
\hline Jebba - Minna & $1909-1915$ & $225 \mathrm{~km}$ \\
\hline Port - Harcourt - Enugu & $1914-1916$ & $243 \mathrm{~km}$ \\
\hline Enugu - Markurdi & $1916-1924$ & $220 \mathrm{~km}$ \\
\hline Kaduna Junction - Kafanchan & $1922-1927$ & $179 \mathrm{~km}$ \\
\hline Kafanchan - Jos & Opened to traffic in 1927 & $101 \mathrm{~km}$ \\
\hline Kuru - Bauchi & $1958-1961$ & $166 \mathrm{~km}$ \\
\hline Bauchi - Gombe & 19611963 & $166 \mathrm{~km}$ \\
\hline Gombe - Maiduguri & $1963-1964$ & $302 \mathrm{~km}$ \\
\hline Ajaokuta - Warri & Under construction & $277 \mathrm{~km}$ \\
\hline Port - Harcourt - Onne & Under construction & $19 \mathrm{~km}$ \\
\hline Source: Nigeria Railway Con & \\
\hline
\end{tabular}

Source: Nigeria Railway Corporation (2002)

ensure safety of operations and maximum efficiency, meet social responsibility in a manner that will meet the requirements of rail users, trade, commerce, industry, government and the general public (Nigerian Transport Profile, 1993). Initially, the Nigerian Railway Corporation was part of the civil service until 1955 when it became a public enterprise by an Act of Parliament (no. 26) of 1955.

Development of the rail industry was promoted by the discovery of coal in Enugu in 1914 and that led to the construction of the rail line from Port - Harcourt to Enugu which facilitated the export of coal through Port-Harcourt. In a way, the history of the Nigerian Railway system epitomizes the history of geographical area now known as Nigeria. The amalgamation of Northern Nigeria and the Southern Protectorates in 1914 had a parallel in the amalgamation of Lagos Government Railway and the Baro Kano Railway in 1912 when the Nigerian Government Railway was established (Nigerian Railway Corporation, 1998).

Commencing in 1989 with $193 \mathrm{~km}$ snaking from Ebute Metta to Ibadan, at a cost of $£ 100,000$ per mile, the system which was steam - driven until the mid 1950s experienced continual extensions viz. Ibadan to Jebba $295 \mathrm{~km}$ 1901 -1909; Kano to Baro 562 km 1907-1911; Jebba to Minna 255 km 1909-1915; Port-Harcourt to Enugu 243 km 1914-1916, Enugu to Makurdi $220 \mathrm{~km} \mathrm{1916-1924;}$ Kaduna to kafanchan $179 \mathrm{~km} 1922$ - 1927(See Table 1). In the thirty-one years from 1927 to 1958 there was no railway development. Further development from 1958 took the tracks from Kafanchan to Bauchi in 1961 (238 $\mathrm{km}$ ) and ultimately to Maiduguri in 1964(302) km.

The Nigerian Railway Corporation is 113 years old and it runs a unilaterally designed track system of $1067 \mathrm{~mm}$ narrow gauge. Only $30 \mathrm{~km}$ of its track distribution is in double track (within Lagos area). Nigerian Railway System actually commenced rail business activities with the construction of the first rail line from Lagos to Ibadan $(193 \mathrm{~km})$ between 1898 and 1901. By 1964 when the construction of $640 \mathrm{~km}$ Kano-Maiduguri rail line, then known as Bornu extension, was completed, the present core of the railway network had been put in place. Presently, the Railway system is made up of 3505 route kilometres and 4332 track kilometres. In addition to this is the $19 \mathrm{~km} 1067 \mathrm{~mm}$ gauge extension from Port-Harcourt to Onne deep sea port and the $277 \mathrm{~km}$ standard gauge rail construction of $1435 \mathrm{~mm}$ from Ajaokuta to Warri. Out of the 3505 kilometres of rail network, 1055 kilometres consist of curved track, thus making the maximum permissible speed on the rails to only about 65 kilometres per hour, whereas the main line locomotives are calibrated for speeds of 110 kilometres per hour. However, most of the tracks (rail, sleeper, ballast and the formation) are damaged and are overdue for replacement. The poor condition of the track reduces efficiency and may lead to derailment.

The dilapidated nature of the present railway infrastructure was caused by years of neglect by successive governments which accorded the railway system a very low position in its programme. On a macro-level, the problem of the railway today is after-effect of the collapse of the agrarian economy. The decline in agricultural produce in the early 70's, was a consequential effect of the discovery of oil/petroleum. The result was the absence of appeal and interest in the business of agriculture which was our economic mainstay contributing about $93 \%$ of our national income and providing well of $75 \%$ of Nigeria's total working population.

The reduction in agricultural activities following the emergence of petrol economy led to low output of agricultural produce necessitating redundancy in the existing rail facilities because of capacity under utilization. Secondly, agricultural activities were no longer attractive thereby necessitating a shift in attention and government policies. With petrol, the government's capital expenditures would obviously have geared toward providing infrastructure to facilitate exploration and exploitation of the new economic gold. This development led to large constructions of refining plants, laying of pipelines, procurement of technology - capital equipment plus expertise.

Being that the agricultural sector is the biggest sectoral market for the survival and growth of the railway corporation, therefore in a macro view; the ailing railway had its pathological history traceable to the dwindling agricultural activities occasioned by government's neglect of them (Nigerian Transport Profile, 1993). However, the government has regretted the neglect of yesteryears and a programme to resurrect the rail system is being fashioned out (Nigerian Transport Profile, 1993). The Federal Gov- 
ernment has proposed to construct the following new lines: Port-Harcourt- Onne narrow gauge $(1067 \mathrm{~mm})$, to connect the Onne port-19 km long, the Lagos-Abuja Express Line, the East -West Rail line, the Kaduna-Abuja Rail line, the Minna-Abuja line, the Ajaokuta-Otukpo Rail line and the Ajaokuta- Baro Rail line (Abubakar, 2002)

\section{Rail Transport in Lagos}

The need to have an efficient railway system in Lagos was probably not recognized until about 1879 . Between 1879 and 1892, private (United Kingdom) interests made various applications to the colonial office for concession to construct railways not only in Lagos but across Nigeria. But because the colonial government was unable to guarantee interest on the capital sum required for the construction, the applications were not approved (Labisi, 1999).

A preliminary survey was however ordered in 1892 by the Secretary of State for the colonies to estimate the cost of railway construction. The survey showed great potentials for trade and in 1895, the Secretary of State for the colonies sanctioned the construction by the colonial government of a railway line from Iddo to Otta, a distance of $32 \mathrm{~km}$ (Labisi, 1999). Also, the tramway system was developed to convey people from one point to the other within Lagos. Actual work on the first line from Iddo to Otta commenced in 1898 and other lines from the South to the North were constructed thereafter. The Nigeria Railway Corporation (NRC) was established in 1912 by the amalgamation of the Lagos Government Railway and the Baro-Kano Railway. It originally operated within the Nigerian Government Railway Department, subsequently becoming an autonomous public corporation through the Nigerian Railway Corporation Act of 1955, as amended in the Laws of the Federation of Nigeria 1990. Its main objective was to offer optimal services for the carriage of persons and goods to the population.

In Lagos, the Nigerian Railway Corporation (NRC) renders both passenger and cargo services. The passenger services involve the movement of commuters from the northern part of Lagos State towards Iddo and Apapa in particular, at cheaper rates than is possible with the road system. Also passengers are carried from Iddo and other stations within Lagos district of NRC by express train to the northern parts of the country. The cargo service involves the transportation of farm produce and bulky raw materials from the hinterlands to the southern parts of the state. For this service, there is the Lagos to Idogo farm produce cargo train that mainly carries vegetables, fruits, cassava and maize. There is also the Iddo-Apapa bulky raw materials coach that conveys raw materials to the
Apapa port (after arriving at Iddo from the hinterland) for exportation. However, because these services are inefficient and underutilized, the entire transport system in Lagos, especially road, is highly overstressed lacking in capacity to cope with persistent increase in population, thus leading to widespread road congestion. Oni (2004) has suggested that high-capacity mass-transit system most appropriate for travel-demand corridors in which the peak hour demands exceed 20,000 persons per hour should be established.

To meet the city's long-term requirements, LAMATA has developed plans for a seven-line rail network totalling about $246 \mathrm{~km}$. This is due to be completed by 2025 . The first stage comprises two lines which are to be built by 2011. The two rail lines are the Red Line (Agbado to Marina) and Blue Line (Okokomaiko to Marina). The Red Line is a 31-kilometre rail route designed to have a sixkilometre spur to the Murtala Muhammed International Airport while the Blue Line would span 27 kilometres. The two lines would meet at Iddo and they will run across the lagoon to Marina by a suspension bridge to be specially constructed for that purpose (Alao, 2008). With the plans for the Red and Blue lines well underway, longerterm proposals are taking shape for a further five lines(Green, Yellow, Brown, Orange and Purple lines) to complete the $246 \mathrm{~km}$ network by 2025 (Mobereola, 2008).

The Green Line would run east from Marina to Lekki airport, paralleling the coast, while the Yellow Line would diverge from the Blue Line at National Theatre near Iddo and head northwest to Otta in Ogun State. A short branch off the Red Line at Oshodi would serve the international and domestic terminals at Murtala Mohammed International Airport.

The Brown and Orange lines would serve the northeast, sharing the Red Line tracks from Marina to Jibowu and then running to another junction at Ojota. The Brown Line would finish at Mile 12, while the Orange Line would continue north through Long Bridge to Redeem Camp in the satellite township of Mowe/Ibafo. Finally Purple Line would provide an orbital route running from Ojo in the west to Lagos-Ibadan Expressway Toll Gate in the northeast, where it would join the Orange Line tracks to Redeem (See the proposed Lagos Urban Rail network in Fig. 1). Interchanges would also be provided with the Yellow and Red lines in the northern suburbs. In addition, a monorail ring around Lagos Island is envisaged to serve the city centre.

The design of the mass transit rail project has been completed, paving way for the construction of the project with immediate effect. The first phase will include the construction of the Blue Line which is expected to be delivered by 


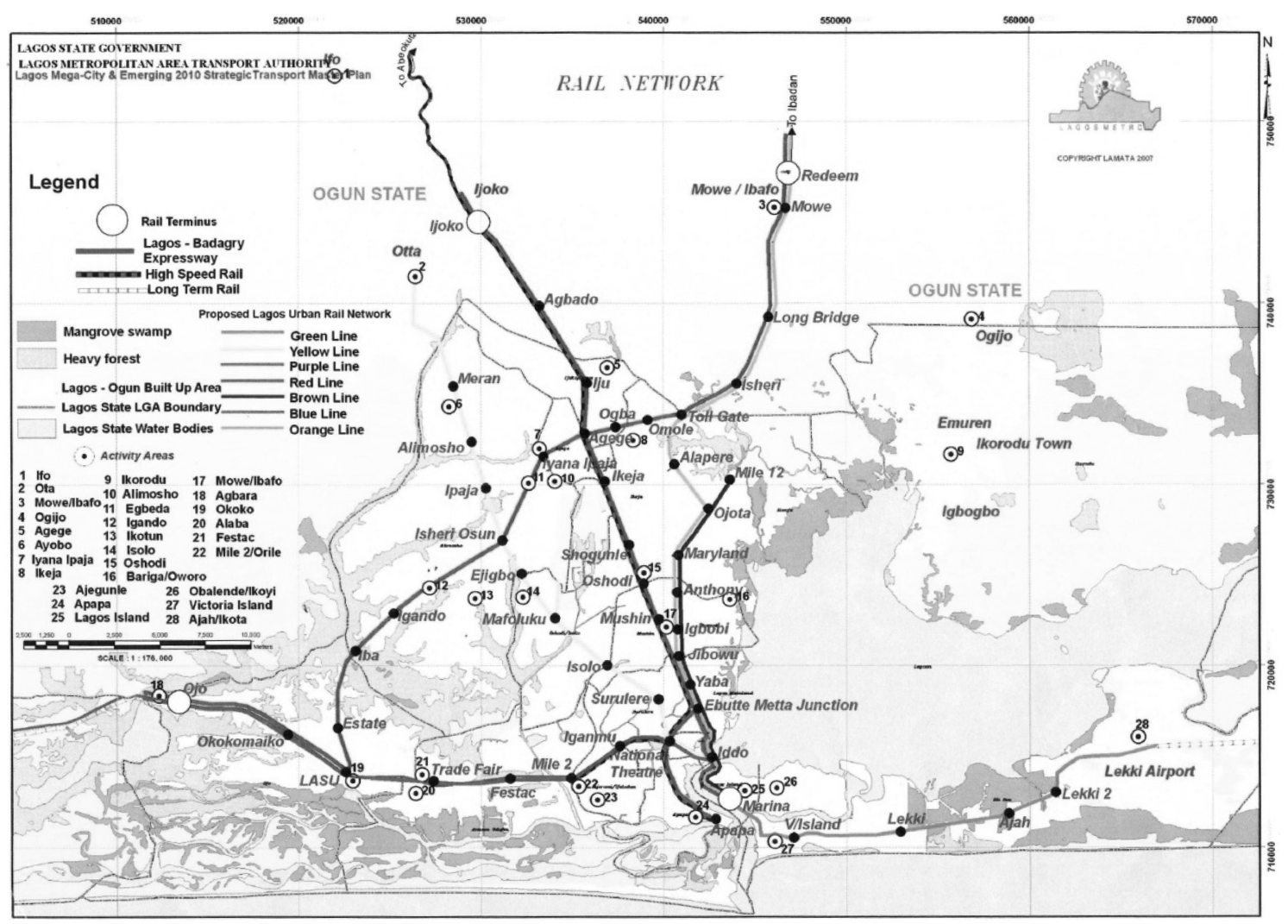

Fig. 1 The proposed Lagos Urban Rail network

Table 2. Passengers Carried by LMTT at Each Station in 2007

\begin{tabular}{|c|c|c|c|c|c|c|c|c|c|c|c|c|c|}
\hline Stations & JAN & $\mathrm{FEB}$ & MAR & APRIL & MAY & $\mathrm{JUN}$ & JULY & AUG & SEPT & OCT & NOV & DEC & Grand Total \\
\hline ljoko & 7,958 & 12,553 & 10,386 & 7,010 & 10,114 & 9,536 & 15,136 & 15,782 & 18,072 & 20,854 & 23,541 & 12,710 & 163,652 \\
\hline Itoki & 6,255 & 7,076 & 6,955 & 4,676 & 6,242 & 5,452 & 7,497 & 7,808 & 8,642 & 9,623 & 9,557 & 4,633 & 84,416 \\
\hline Agbado & 23,143 & 27,112 & 24,899 & 14,800 & 21,723 & 23,590 & 38,137 & 39,885 & 46,020 & 51,133 & 57,081 & 26,288 & 393,811 \\
\hline ju & 2,540 & 2,926 & 2,282 & 1,225 & 2,008 & 2,299 & 4,334 & 4,683 & 5,873 & 6,586 & 7,018 & 2,956 & 44,730 \\
\hline Agege & 844 & 813 & 660 & 277 & 613 & 958 & 1,692 & 1,857 & 2,981 & 3,559 & 3,588 & 1,325 & 19,167 \\
\hline Ikeja & 1,974 & 2,116 & 1,459 & 477 & 1,166 & 1,850 & 2,821 & 3,637 & 5,631 & 5,270 & 5,610 & 2,002 & 34,013 \\
\hline Shogunle & 736 & 847 & 760 & 377 & 742 & 1,736 & 2,940 & 3,522 & 4,818 & 4,634 & 5,361 & 2,140 & 28,613 \\
\hline Oshodi & 4,898 & 4,932 & 4,413 & 1,887 & 1,101 & $\mathrm{Nl}$ & $\mathrm{Nil}$ & $\mathrm{Nil}$ & $\mathrm{Nil}$ & $\mathrm{Nil}$ & $\mathrm{Nl}$ & $\mathrm{Nil}$ & 17,231 \\
\hline Mushin & 4,686 & 5,170 & 4,289 & 2,127 & 3,588 & 4,768 & 7,644 & 7,047 & 10,677 & 10,424 & 10,633 & 4,658 & 75,711 \\
\hline Yaba & 4,018 & 4,511 & 3,246 & 3,020 & 2,334 & 3,286 & 4,833 & 5,642 & 7,921 & 7,578 & 8,366 & 3,490 & 58,245 \\
\hline Ebute Metta Juntion & 4,263 & 5,171 & 4,128 & 2,187 & 3,403 & 3,926 & 6,325 & 7,559 & 6,415 & 6,282 & 6,203 & 2,735 & 58,597 \\
\hline Eoute Metta & 6,440 & 8,054 & 6,094 & 3,410 & 4,906 & 6,180 & 10,466 & 12,495 & 7,691 & 6,482 & 5,524 & 2,654 & 80,396 \\
\hline Iddo & 3,172 & 4,053 & 4,229 & 2,517 & 3,203 & 4,269 & 7,363 & 8,319 & 16,510 & 22,347 & 29,560 & 15,245 & 120,787 \\
\hline Iganmu & 621 & 773 & 920 & 547 & 696 & 756 & 927 & 1,547 & 2,424 & 3,182 & 3,140 & 1,386 & 16,919 \\
\hline Apapa Local & 2,181 & 2,836 & 2,465 & 1,353 & 1,570 & 2,139 & 3,000 & 4,458 & 6,764 & 9,433 & 10,364 & 4,728 & 51,291 \\
\hline Total & 30,279 & 35,500 & 29,784 & 17,048 & 20,801 & 25,324 & 40,558 & 47,067 & 150,439 & 167,387 & 185,546 & 86,950 & 564,187 \\
\hline
\end{tabular}

Source: Nigerian Railway Corporation, Lagos District (2008)

August 2012 (Akinsanmi, 2010). On the Red Line rail construction, the Lagos State Government is waiting for the approval of the Federal Government to use its corridor to link Iddo through Agbado and Ijoko in Ogun State.
If the urban rail network is completed as planned, it would reduce traffic congestion and improve road safety, increasing travel efficiency and productivity across the whole region. It offers the potential to improve the quality 
Oni, S. I. and Okanlawon, K. R. / IJR, 5(1), 29-37, 2012

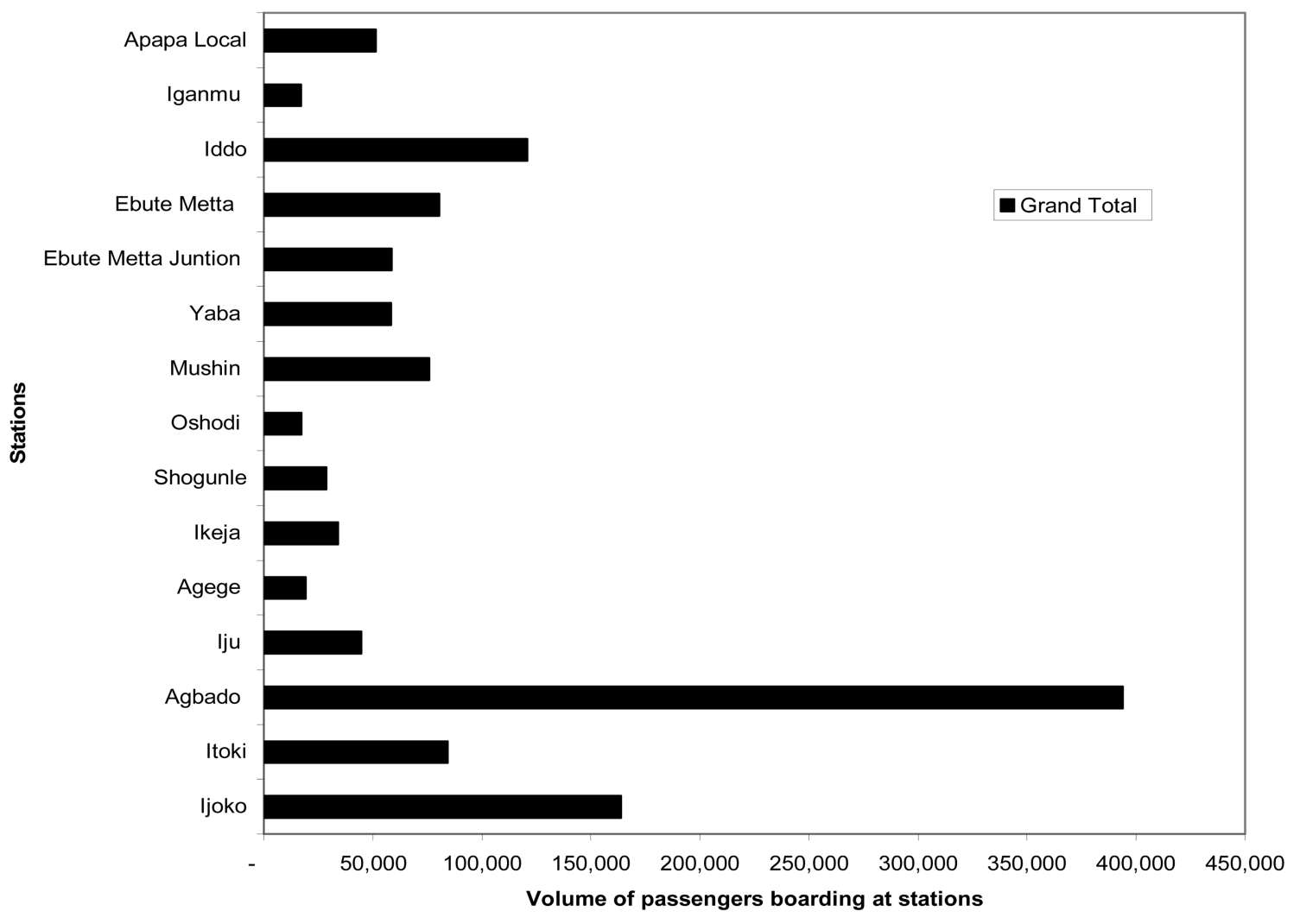

Fig. 2 Volume of Passenger boarding at stations in 2007

Table 3. Passengers Carried and Revenue Generated Yearly by LMTT (2000-2009)

\begin{tabular}{|r|r|r|}
\hline \multicolumn{1}{|l|}{ Year } & Number of passengers carried & Revenue $\mathbb{A}$ \\
\hline 2000 & 569,448 & $29,246,320$ \\
\hline 2001 & 834,869 & $35,390,920$ \\
\hline 2002 & 670,333 & $32,429,270$ \\
\hline 2003 & $1,068,260$ & $64,310,755$ \\
\hline 2004 & $1,332,008$ & $64,799,919$ \\
\hline 2005 & 621,820 & $52,900,415$ \\
\hline 2006 & 577616 & $39,986,460$ \\
\hline 2007 & 1310,439 & $77,140,400$ \\
\hline 2008 & 1,787695 & $159,866,490$ \\
\hline 2009 & 1,097613 & $128,295,160$ \\
\hline Total & $9,870,101$ & $684,366,109$ \\
\hline
\end{tabular}

Source: Nigerian Railway Corporation, Lagos District (2010)

of the environment as well as raising living standards. Investment in the rail network would promote the spread of economic activity throughout the city and ultimately contribute to the creation of an integrated multi-modal passenger transport network.

\section{Methodology}

This study utilized secondary data obtained from the
Table 4. Volume of Passengers Carried by NRC and LMTT from 2000-2009

\begin{tabular}{|c|c|c|c|}
\hline Year & $\begin{array}{l}\text { Number of passengers } \\
\text { canied by NRC }\end{array}$ & $\begin{array}{l}\text { Number of passengers } \\
\text { canied by LMTT }\end{array}$ & $\begin{array}{l}\text { of Contribution of } \\
\text { LMTT to MRC }\end{array}$ \\
\hline 2000 & 2610435 & 569,448 & $218 \%$ \\
\hline 2001 & 1284,022 & 834,869 & $65.0 \%$ \\
\hline 2002 & 942594 & 670,333 & $71.1 \%$ \\
\hline 2003 & 1608,447 & $1,068,260$ & $66.4 \%$ \\
\hline 2004 & 1751.159 & $1,332.008$ & $76.1 \%$ \\
\hline 2005 & 752,842 & 621.820 & $82.6 \%$ \\
\hline 2006 & 708,802 & 577,616 & $81.5 \%$ \\
\hline 2007 & $1,478,700$ & $1,310,439$ & $88.6 \%$ \\
\hline 2008 & 1996,324 & $1,787,695$ & $89.5 \%$ \\
\hline 2009 & 1285,080 & 1097.513 & $85.4 \%$ \\
\hline Total & $14.418,405$ & $9,870,101$ & $68.5 \%$ \\
\hline
\end{tabular}

Source: Okanlawon, 2011

Nigerian Railway Corporation. These include data on Passengers carried by LMTT at each station in 2007, Passengers carried and Revenue generated yearly by LMTT (2000-2009), Volume of passengers carried by NRC and LMTT from 2000-2009 and Commodities hauled by Lagos District of NRC in 2007. Relevant information was also obtained from textbooks, articles, reports, and internet.

The data collected were presented in Tables 2-5. The following secondary data were utilized in this study:

- Passenger Traffic Flow along the Route of the Lagos Mass Transit Trains (shown in Table 2 and Fig. 2). 
An Assessment of the Usage of the Lagos Mass Transit Trains

Table 5. Commodities Hauled by Lagos District of NRC in 2007

\begin{tabular}{|c|c|c|c|c|c|}
\hline Month & Commodity & Wagons & Tons & Point of Origin & Point of Destination \\
\hline \multirow[t]{4}{*}{\begin{tabular}{|l|} 
January \\
\end{tabular}} & Car & 80 & 160 & Apapa Local & Kaduna \\
\hline & Cement & 12 & 466 & Apapa Quay & Zaria \\
\hline & Billet & 9 & 302.005 & Ebute Metta & Bukuru \\
\hline & \multicolumn{2}{|c|}{\begin{tabular}{|l} 
Luggage \& Parcel / Countryproduce(350kg) \\
\end{tabular}} & & & \\
\hline \multirow[t]{5}{*}{ February } & Car & 40 & 80 & Apapa Local & Kaduna \\
\hline & Cement & 12 & 448 & Apapa Quay & Kano \\
\hline & Billet & 20 & 1161.09 & Ebute Metta & Bukuru \\
\hline & Wheat & 36 & 1241.06 & Apapa Local & Kano \\
\hline & \multicolumn{2}{|c|}{ Luggage \& Parcel / Country produce $(1850 \mathrm{~kg})$} & & & \\
\hline \multirow[t]{3}{*}{ March } & Cement & 12 & 465 & Apapa Quay & Kano \\
\hline & Wheat & 12 & 416.29 & Apapa Local & Kano \\
\hline & \multicolumn{2}{|c|}{ Luggage \& Parcel / Country produce(1950kg) } & & & \\
\hline \multirow[t]{3}{*}{ April } & Car & 12 & 36 & Apapa Local & Kano \\
\hline & Wheat & 12 & 416.58 & Apapa Local & Kano \\
\hline & \multicolumn{2}{|c|}{ Luggage \& Parcel / Country produce $(800 \mathrm{~kg})$} & & & \\
\hline \multirow[t]{3}{*}{ May } & Wheat & 24 & 829.62 & Apapa Local & Kano \\
\hline & Car & 12 & 40 & Apapa Local & Kaduna \\
\hline & \multicolumn{2}{|c|}{ Luggage \& Parcel / Country produce } & & & \\
\hline \multirow[t]{3}{*}{ June } & Wheat & 23 & 766.55 & Apapa Local & Kano \\
\hline & Cement & 12 & 465 & Apapa Local & Kano \\
\hline & \multicolumn{2}{|c|}{ Luggage \& Parcel / Country produce(1360kg) } & & & \\
\hline \multirow[t]{3}{*}{ July } & Wheat & 24 & 827.9 & Apapa Local & Kano \\
\hline & Cement & 7 & 275.1 & Apapa Local & Kano \\
\hline & \multicolumn{2}{|c|}{ Luggage \& Parcel / Country produce $(4840 \mathrm{~kg})$} & & & \\
\hline \multirow[t]{3}{*}{ August } & Wheat & 12 & 413.6 & Apapa Local & Kano \\
\hline & Cement & 12 & 471 & Apapa Quay & Zaria \\
\hline & \multicolumn{2}{|c|}{ Luggage \& Parcel / Country produce $(5665 \mathrm{~kg})$} & & & \\
\hline September & \multicolumn{2}{|c|}{ Luggage \& Parcel / Country produce(12450) } & & & \\
\hline October & \multirow{2}{*}{\multicolumn{2}{|c|}{ Luggage \& Parcel / Country produce $(17637 \mathrm{~kg})$}} & & & \\
\hline November & & Luggage \& Parcel / Country produce $(16220 \mathrm{~kg})$ & & & \\
\hline \multirow[t]{2}{*}{ December } & Wheat & 24 & 830.87 & Apapa Local & Kano \\
\hline & \multicolumn{2}{|c|}{ Luggage \& Parcel / Country produce(21990kg) } & & & \\
\hline
\end{tabular}

Source: NRC, Lagos district (2007 and 2008)

- Passengers Carried Yearly by Lagos Mass Transit Trains (presented in Table 3).

- Contribution of LMTT to NRC (revealed in Table 4).

- Commodities hauled by Lagos District of NRC in 2007 (presented in Table 5)

\section{Findings/Discussion}

\subsection{Usage of the lagos mass transit train}

The Lagos District of Nigerian Railway Corporation plays leading roles in operational activities of the NRC. Some of these operational roles are: conveying both local and imported goods from Lagos to the hinterland, running express passenger trains from Lagos to Kano, running intra-city and suburban mass transit trains for workers from satellite towns that surround Lagos, organizing tourist trains for school children and holiday makers and provision of party, picnic and social gathering ground in the forecourts (URL 3).
In order to determine the actual usage of the present Lagos mass transit train, available data on the number of passengers carried on monthly and yearly bases by the present LMTT were collected and used to determine the passenger traffic flow along the route of the LMTT and the average number of passengers carried yearly by LMTT.

\subsection{Passenger traffic flow along the route of the lagos mass transit trains}

As shown in Fig. 2 and Table 2, for a period of 1 year (Jan.-Dec. 2007), Agbado station recorded the largest number of passengers $(393,811)$, followed by Ijoko $(163,652)$ and Iddo $(120,787)$ while Iganmu station has the lowest number of rail commuters $(16,919)$. This reveals that the greater part of Lagos inhabitants are not benefiting from the use of the rail mass transit because the rail route in the mainland does not get to most parts of the state. The number of passenger carried in the month of April was lower 
due to the 2007 general elections while Oshodi station got burnt in May 2007. Since then passengers have not been boarding the train at Oshodi station.

\subsection{Passengers carried yearly by lagos mass transit trains}

As shown in Table 3, for a period of 10 years (20002009), Lagos mass transit trains generated N 684,366,109 and carried a total of $9,870,101$ passengers, which gives an average of 987,010 passengers annually. Table 3 reveals that between 2000 and 2009, the railway carried less than 2 million passengers yearly in the whole of Lagos. If this scenario is put in comparative perspective with the Indian experience, which (according to the Cable News Network, 2006) operates 14,000 trains per day and carries an average of 16 million passengers per day, the sorry state of the Nigerian railway becomes glaring.

\subsection{Contribution of LMTT to NRC}

NRC carried a total number of $14,418,405$ passengers in the whole country between 2000 and 2009 out of which LMTT carried 9,870,101 passengers, which is $68.5 \%$ of the total (Okanlawon, 2011). This shows that LMTT contributes immensely to NRC by carrying $68.5 \%$ of the total passenger traffic of NRC, while the remaining $31.5 \%$ was carried by all the other NRC districts in the country (See Table 4).

\subsection{Commodities hauled by lagos district of NRC in 2007}

As shown in Table 5 the major commodities hauled by the Lagos district of NRC in 2007 are cars, cement, billet and wheat. These products are hauled by freight trains from Apapa local, Apapa Quay and Ebute Metta in Lagos to the northern parts of the country. A total of 10,112 tonnes of freight (using 407wagons) were carried by Lagos district in 2007. No major freight was carried between September and November except for luggage and parcel/country produce carried by the LMTT due to the collapse of the rail bridge in Abeokuta.

\section{Conclusion}

For a period of 10 years (2000-2009), Lagos mass transit trains carried a total of 9,870,101 passengers, which gives an average of 987,010 passengers annually. This suggests that the service of the Lagos mass transit train is grossly underutilized. However, LMTT contributes enormously to NRC by carrying $68.5 \%$ of the total passenger traffic of NRC between 2000 and 2009. In terms of passenger traffic flow along the route of LMTT, for a period of 1 year (January - December 2007), Agbado station recorded the largest number of passengers $(393,811)$, followed by Ijoko $(163,652)$ and Iddo $(120,787)$, while Iganmu station has the lowest number of rail commuters $(16,919)$. This indicates that a vast majority of the workers in Lagos live far away from their work places and that a greater part of Lagos inhabitants are not benefiting from the use of the mass transit trains because the rail route in the mainland does not cover most parts of the state. Consequently, there is the need for urgent revitalization of railway system in Lagos/Nigeria to prevent the total collapse of the railway sector. Also, the Federal Government should urgently repeal the Nigerian Railway Act of 1955 to allow private participation in the development and operation of rail transport in Lagos.

\section{References}

1. Adefolalu, A. A. (1993). Bottlenecks and other Constraints to Traffic Flow in the Lagos Metropolitan Area. In Nigerian Transport Handbook and Who's Who, Media Research, Lagos.

2. Akinsanmi, G. (2010). Lagos Begins N170bn Rail Project. Retrieved March 10, 2010, from http://www.thisdayonline.com/nview.php?id=164702

3. Alao, T. (2008). Lagos in $\$ 2 \mathrm{~b}$ rail lines project drive. Retrieved December 12, 2008 from http://www.ngrguardiannews.com/business/article01//indexn2_html?pdate $=101108 \&$ ptitle $=$ Lagos $\% 20$ in $\% 20 \$ 2 \mathrm{~b} \% 20$ rail $\% 20$ lines $\% 20$ project $\% 20$ drive

4. CNN (2006). Indian Railway Operation for the Year 2006. By the Rail Minister Sajaw. December 29, 2006.

5. International Labour Organization (1994). Tripartite Meeting on the Consequences for Management and Personnel of the Restructuring of Railways. Geneva: International Labour Office.

6. Labisi, A. (1999). Rail Transport. In Balogun Y. et al. (Eds.), Lagos State in Maps, Ibadan: Rex Charles Publication in Association with Connel Publications, pp. 66-67.

7. LAMATA (2006). Light Rail Mass Transit-An Idea Whose Time Has Come. LAMATA Bulletin, 4. Lagos, pp.1-15.

8. Mabogunje, A.L. (2007). Developing Mega Cities in Developing Countries, A lecture delivered at a Colloquium organized by the 2007 Graduating Class, Department of Geography, University of Lagos, September, 2007, pp.1-30.

9. Mobereola, D. (2008). Africa's megacity needs an urban rail backbone. Retrieved October 6, 2008 from http://www.railwaygazette.com/news/single-view/view//africas-megacityneeds-an-urban-rail-backbone.html

10. National Transport Policy (1993). Federal Ministry of Transport. Main Document, 5.

11. Nigerian Railway Corporation (1998). Report of the Committee on the Problems of Operational Sustainability of the NRC, pp. 38-39. 
An Assessment of the Usage of the Lagos Mass Transit Trains

12. Nwanze, E. (2002). Conceptualization of the Nigerian Transport Problems and the Need for an Integrated National Transport System. Paper presented at the Conference on Revitalization of Railway Transport in Nigeria at the Centre for Transport Studies, Olabisi Onabanjo University, AgoIwoye, August, 2002.

13. Okanlawon, K. R., (2011). A Study of Rail Mass Transit in Lagos and its Environs, Germany, Lambert Academic Publishing, 2011, P.64.

14. Olanrewaju, S. A. (1986). Transport in Nigeria's Economic Setting. In Toyin, F. \& Olanrewaju, S. (Eds.), Transport Systems in Nigeria. New York: Maxwell School of Citizenship and Public Affairs, Syracuse University.

15. Oni, S. I. (2004). Development of Urban Transportation. In
Vandu-Chikolo et al. (Eds.), Perspectives on Urban Transportation in Nigeria. Zaria: Nigerian Institute of Transport Technology, pp.53-69.

16. Rodrigue, J. \& Slack, B. (2009). Rail Transportation and Pipelines. Retrieved April 15, 2009 from http://people.hofstra.edu/geotrans/eng/ch3en/conc3en/ch3c2ben.html

17. URL1: High-speed rail (n.d.). In Wikipedia, the free encyclopedia. Retrieved October 15, 2009 from http://en.wikipedia.org/wiki/High-speed_rail

18. URL 2: Lagos Urban Rail Mass Transit Scheme from Iddo to Ijoko (2010, July 1). Retrieved from http://www.lamatang.com/rail_services.html

19. URL 3: Retrieved May 5, 2009 from http://www.nrc-ng.org/

Received(March 8, 2012), Accepted(March 15, 2012) 